\title{
Beyond Gardens and Nature Reserves: Contemporaneous Landscapes
}

\author{
Jennifer Buyck and Teodoro C. Vales
}

\begin{abstract}
There have been many attempts at providing definitions of landscape, and many points of view have been expressed. The word paysage is not based on a latin one, which explains the lack of consensus as regards its meaning. The word appears to be based on the term pays, which refers to a physical environment. The Littré dictionary mentions that paysage (landscape) is both "an area of flat land which can be observed" and "a country-style type of painting." The word therefore has several meanings and is very widely used. But what landscape are we talking about at a time where everything is part of the landscape? The word is overused and this results in confusion. What role did the pays play in the invention of paysage? What is the place of nature in it? What is the relationship between man and landscape?
\end{abstract}

Keywords Landscape - Contemporaneous landscape - Landscape concept • Cultural heritage $\cdot$ Nature

\subsection{About Landscapes}

The word and notion paysage is believed to have originated in the Netherlands, around 1415. The term was then used in Italy, where it was influenced by works related to perspective. Until then, landscape was only used as a scene. It later became the main object of paintings. The status of landscape progressively changed (Mérot 2009). Originally, landscapes were visible through windows and were part of indoor scenes. Windows and views then absorbed the rest of the paintings to the point where they actually became the paintings.

As a framing device, the window helps to understand the origin of the word paysage. Pagus is used to delimitate, to fix, to anchor. As a consequence, it is doubly inscribed in reality through the observed environment and through the spectator who is watching.

Natural - and not so natural - landscapes. The Grand Robert dictionary gives three definitions of the word paysage. The first one reads: "part of a country, area of

\footnotetext{
J. Buyck $(\bowtie) \cdot$ T.C. Vales

Institute d'Urbanisme de Grenoble, 14, avenue Marie Reynoard, 38100 Grenoble, France

e-mail: jennifer.buyck@upmf-grenoble.fr; teovales@yahoo.co.uk
} 
land offered by nature to an observer" (Rey 1992). This definition is somewhat ambiguous because of the use of the term "nature" which should be defined. Looking around us, we can wonder what part of nature is not artificial. Is there such a thing as a natural space? Parks and gardens have been planted by man for man. Rural areas, with their farms, are also spaces of culture. The first definition which the Grand Robert dictionary gives therefore reflects a vision of landscape as "site," "view," or "décor." The second definition is related to the pictorial origin of the word: "pictorial or graphic figuration of an area of land in which nature is central whereas figures (men or animals) and buildings are secondary" (Rey 1992). The last definition is figurative. Paysage thus becomes a "general aspect," a "situation," and allows to establish the state of the art in various fields.

It is the first definition, which is of most interest to us here, the two others being relative to painting and state of the art. Many dictionaries give three such definitions of the word paysage. The first definition given by Dictionnaire de la langue française d'Emile Littré is of particular interest: "area of land that can be seen as a whole" (Littré 1994). This definition appears to be separate from "nature" - the definition of which could be even more difficult to reach than that of landscape - but it does not highlight the subjectivity of the individual facing the landscape.

Landscape and its vocabulary. Vocabulary related to landscape does not provide much help in understanding this definition confused. Let us take the word paysagiste (landscape architect). According to the Grand Robert dictionary, a paysagiste is both an artist who paints landscapes and someone who draws garden plans, and who designs green spaces in cities (Rey 1992). The same word is therefore used to talk about different disciplines, whether artistic or not. It can indeed refer to a painting that aims at representing land, trees, or flowers, with various degrees of artistic subjectivity. Similarly, the word paysagisme, as "art and technique of landscape" (Rey 1992), is just as slippery. The words paysagé or paysager, however, are much clearer although used more rarely. They are defined as follows: "arranged in a manner that creates a natural landscape effect" (Rey 1992).

Landscape outside France. The English language offers many definitions of landscape, just like French does. The Oxford English Dictionary (Simpson and Weiner 1998) states that landscape is a "picture representing natural inland scenery," or "a view or prospect of natural inland scenery, such as can be taken in at a glance from one point of view," or "the depiction or description of something in words." The vocabulary of landscape is however very clear: a landscape architect works on "the planning of parks of gardens to form an attractive landscape, often in association with the design of buildings, roads." An artist who paints landscapes is referred to as a landscape painter or landscapist. Confusion is impossible.

The word pays is the basis of many Western words meaning landscape: landschaft in Germany, landschap in the Netherlands. Similarly, the word "land" is used to refer to pays in both cases. In Italy, the word paesaggio is used to talk about landscape and is based on paese. In Spain, the words paisaje and pais are used. In Greece, topoi means landscape and topos refers to pays. 


\subsection{Nature at the Center of Contemporaneous Landscapes}

Landscape as ready-made. Land is an important notion in landscape, but these should not be confused: it is important to distinguish landscape and its material and physical element features. It is for this reason that Pascal Aubry in Mouvance II: soixante-dix mots pour le paysage chose to define "the invention of landscapes" (Berque 2006) rather than landscape itself. This allows to highlight the fact that landscape is a recognition rather than a creation: "as a landscape, the concrete and pre-existing space can be invented" (Aubry 2006). The invention of landscape is thus a type of ready-made (Duchamp 1998) in which the observed space (in this case, pays) is transformed through emotions, along a footpath, for example.

The relation we establish with our environment is not necessarily related to landscape. Pascal Aubry suggests several criteria in the same paper. Firstly, the observation should be made on site and should require all senses. The second point is related to the perception angle, in other words of the visual field. The horizon should be visible. It can be a fictitious line where land and sky meet, but it can also be cultural. The spatial arrangement of the area of land should be such that it can be described. The last point is related to nature. The territory should indeed be depending on this notion.

The concept of nature has been divided into three parts since antiquity - from Cicero to Petrarch. Jean-Pierre Le Dantec's Jardins et paysages, textes essentiels (Le Dantec 1996) points to the meaning of this subdivision. The site, or wilderness, refers to untouched nature, independent from human activity. Cultivated nature, in other words the countryside, refers to the second dimension of nature and includes all human interventions on nature. The third dimension is related to the association and art and nature for the purpose of aesthetics, philosophy, or leisure. These three definitions show that the invention of landscape relies on nature which itself is a complex and multifaceted notion.

Thinking about landscape. Let us now take a closer look at landscape theory. For it to exist, one has to able to represent landscape and use a word to refer to it. There is a difference between landscape theory (pensée du paysage) and pensée paysagère, which does not necessarily require words.

Landscape theory thus entails the following transformation: a collection of physical objects, as previously defined, is transcribed into a visual or mental image. This process generates action: landscape theory leads to action in favor of landscape. Pierre Donadieu considers that today's society is a société paysagiste (Donadieu 2002), in other words a landscape architect society.

\footnotetext{
Arguing that the Western society is a landscape architect means that is pursues two simultaneous goals in building its living environment. On the one hand, it seeks to materialize philosophical, ethical or aesthetics ideals, on the other hand, it wants to control the soft forms of the world to live in, whether as a source of comfort and dreams, or as a testimony of the advent of an ideal world. (Donadieu 2002)
}

This means that the relationship between man and the outside world is guided by two quests: the material satisfaction of physical and biological needs and the 
immaterial satisfaction of psychological and mental aspirations. Today's society refuses to be part of the world it has been given and seeks to build another world. It is for this reason that this society does not limit itself to existing landscapes, which are the result of overwhelming trends and forces. It craves to be someplace else (Hervieu and Viard 2005) and has an unfulfilled desire of purity and serenity. This ideal varies in time and everyone does not share it. But everyone knows where he or she is and where he or she would like to be. This collective dream constantly tries to materialize, in either private or public space. Gardens are material symbols of this desire for landscape.

The garden world. Jean-Pierre Le Dantec defines the word garden ( jardin) as "a portion of territory designed in a unique way and (generally) planted for food production and/or aesthetic purposes" (Le Dantec 2006). Its owners concentrate their efforts on it. They can grow edible or ornamental plants and reveal the symbolic space of their cosmos (Nys 1999). It is partly in this place, which has become symbolic, that the idealized link between nature, home, and civilization can be materialized (Baridon 1998). Mowing the lawn, adding garden gnomes, pruning trees, or allowing plants to grow are some of the choices made by garden aficionados. These choices appear to be trivial. But they are also a reflection of the attention we pay to landscape and to out constant attempt at transforming it.

We previously showed that landscape has two definitions. It can be pictorial, by staging part or all of an area. It can also refer to an area of land, which is being observed. Based on this, the various specialists of landscape - whatever their field of study may be - constantly contribute to the production of research literature through new definitions. These definitions are diverse, but they are all related to pays. As ready-made, landscape creates distance vis-à-vis the land, which is being observed. This distance can consist in the production of visual or mental images and can therefore be said to belong to the field of representation. These representations can be strongly desired or, on the contrary, clearly refused, and they generate an ongoing action from society on landscape.

\subsection{Contemporaneous Landscapes and Design}

Landscape design by landscape designers (concepteurs de paysage) also follows this route since it aims at formulating an idea or an intention in order to physically and immaterially transform the relationship between the country and the people who live in it. Landscape design can therefore be defined as the "intention to design space taking into account the material and immaterial future of an area in order to improve its habitability" (Donadieu 2006). It is therefore about anticipating the spatial and social future of the area being dealt with.

The image-landscape. Landscape, as a possible way of looking at space, is one of many interpretations of an area being observed. The way we look at land is a major aspect of landscape. More generally, this look is inherent in any relation between object and subject. 
The world is not an outside reality which is perceived, for it is an object which establishes it as a world and as an exteriority. Any object is above all an object for someone, just as a subject can be defined in contrast with an object. . the world is the relationship between a subject and an object, and any segregation between one and the other makes no sense. (Staszak 1998)

Geographer and orientalist Augustin Berque suggest we use the concepts of trajection (Berque 2000) and médiance (Berque 1990) to talk about the relations between objects and subjects. Landscape is a reality, which is interior to the subject, who takes ownership of it through images which lie at the basis of any action on landscape. These images are highly distorting, as suggested by Serge Morin in Progrès, paysages et identities dans les hautes terres camerounaises:

Landscape is the (conscious or unconscious) polysemous display of projects, heritage, rules, limits and dynamics of a society in a given space or place. It allows to delimitate and to identify a territory. This way, it is an expression of a certain socio-spatial system $[\ldots]$, it is a built appearance [...] it does not show everything, dissimulates facts and can even distort reality. It is not a mere mirror. (Morin 2001)

As image and reality, this landscape changes all the time. These changes sometimes cause strong social reactions, whatever their scope. These changes in the landscape are produced by changes in the area but also by the evolution of the relationship between society and the landscape it finds in the area. Major trends (Hervieu and Viard 2001) can be identified when it comes to the relationship between landscape and society. But this dialectic is heterogeneous for "each person, based on his own ethics, has an idea of the priorities that should be retained and of the solutions which should be applied" (Donadieu 2002).

Landscape that makes sense. By contemplating and judging the spectacle of the world it lives in, the landscape-architect society builds landscapes, which are most often materialized as photographic images. It turns the world into landscapes that then cause intimate or shared emotions, when in contact with ancient or threatened societies. Landscapes often stage heritage and reflect the difficulty of transmitting cultural goods since these are both material and immaterial. Our society pays great heed to cultural heritage as an "active measure of the past" (Mohen 1999). It is therefore forbidden to forget and memory becomes a duty. Landscape can therefore become heritage. In a similar way, landscape can be considered as a space of nature. At a time when everyone knows natural resources are under major threat (Rio de Janeiro Summit 1992), public authorities are opting for the protection of nature. This way, each area has its own charter setting out the good way to use the place. Everything is naturalized. The landscape is seen to be a resource reservoir. Landscape can also be seen as a territory (Montricher 1995), in other words as an invention of the State (in the past) and of societies which live in it (today). At present, choosing where to live is a real question. The place where we are born is rarely the place where we live in. Areas are therefore becoming increasingly standardized, in order to become places where one will inevitably find the same feature: the "search for the sense of his living environment" (Donadieu 2002).

Landscape transmission. For centuries, man has used his technical power on nature. $\mathrm{He}$ is thus liable for what is done. Today, the European landscape 
convention, published in 2000, is the framework in this field. Nature's timescale that of cycles and seasons has been replaced by a historical timescale. Choices made in this field refer to the assumptions that compose our vision of the world and our project as a society. The perception of landscape by political institutions and by citizens depends on its value. It is assessed and criticized. This value serves as a basis for decisions related to the alteration or preservation (Nora 2001) of landscape. By questioning the value of everyday landscapes, we question the practices of spatial anticipation in the face of the "increasing control which we seek to have on terrestrial and sidereal space to design it and live in it" (Boutinet 2005). The question of value is a complex one. It has various foundations. Value can be considered as a price, as a value which is added to the cost, such as an aesthetic, heritage-related, or environmental interest. These values are contradictory, relative, and arbitrary. The question of landscape transmission is therefore directly linked to the practices of spatial anticipation which always attempt at preempting in order to make the desirable occur. Several attitudes are possible to reach this goal: regulation, knowledge, and imagination of the future. Foresight allows to protect material or immaterial, public or private goods. Landscape is no exception. It is in this context that the French State has taken charge of the protection of listed buildings, natural sites, and landscape. French protection of listed buildings was created in 1913 by chapter II, book IV, of the Code du patrimoine and by décret 2007-487, issued on March 30, 2007. They define the protection of listed buildings as a recognition of public interest for monuments and sites which are more specifically related to art and history. The protection of listed buildings was created in 1913 by chapter II, book IV, of the Code du patrimoine and by décret 2007-487, issued on March 30, 2007. They define the protection of listed buildings as a recognition of public interest for monuments and sites which are more specifically related to art and history. France has a special set up referred to as Zone de Protection du Patrimoine Architectural, Urbain et Paysager (ZPPAUP). It was created on January 7, 1983 by the decentralization laws and was later extended through loi paysage on January 8, 1993. Since February 24, it has been the first article of Code $d u$ Patrimoine. It aims at ensuring the protection of landscape and urban heritage, at enhancing areas and sites that should be protected for historic or aesthetic reasons.

Every day, the numerous inventories currently being carried out for listed buildings, natural heritage, landscapes of outstanding beauty and natural zones with an ecological, faunistic, or floristic interest show what is under threat in order for the State to anticipate the spatial future through regulation. The inventory of natural zones of ecological, faunistic, and floristic interest (ZNIEFF) is a program launched by Loi Bouchardeau, dates July 12, 1983. But the current quest for landscape anticipation does not stop here. Attempts at predicting the evolution of the land that surrounds us are numerous. They belong to the field of prospective. The anticipation race reaches its climax with our will to imagine our future. According to Pierre Donadieu, it is the favorite type of anticipation for our landscape architect society (Donadieu 2002). Inventing the future of our landscapes means having an influence either on land itself or on the way we look at it in order 
for it to appear as landscape. Imagining the future can take many forms, from ideas to materialization.

Lastly, projects (Donadieu 2006), and in particular those related to landscape, are operatory anticipations of the desirable future of our land. They can follow current trends or can be at odds with them. In any case, the main goal of a project is to favor land's habitability (Lévy 2002). The question of habitability is central here. Is landscape anticipation a guarantee of a better life? This question is still raised. In any case, it is clear that our current practices make our society liable in terms of landscape. As Javier Maderuelo said, we believe that "si el paisaje que estamos construyendo, no es satisfactorio, entonces es que nos estamos equivocando" (Maderuelo 2005). In other words, "if the landscape we are building does not satisfy us, we are going down the wrong road."

\section{References}

Aubry P (2006) Mouvance: du jardin au territoire II, soixante-dix mots pour le paysage. Ed. de la Villette, Paris, pp 55-56

Baridon M (1998) Les jardins: paysagistes, jardiniers, poètes. Robert Laffont, Paris, p 1239

Berque A (1990) Médiance de milieux en paysages. Reclus, Montpellier, p 162

Berque A (2000) Ecoumène: introduction à l'étude des milieux humains. Belin, Paris, p 271

Berque A (2006) Mouvance: du jardin au territoire II, soixante-dix mots pour le paysage. Ed. de la Villette, Paris, p 119 (A)

Boutinet JP (2005) Anthropologie du projet. Presses Universitaires de France, Paris, p 405

Donadieu P (2002) La Société paysagiste. Actes Sud, Arles, p 150

Donadieu P (2006) "Projet de paysage", Mouvance: soixante-dix mots pour le paysage. Ed. de la Villette, Paris, pp 85-86 (B)

Duchamp M (1998) Marcel Duchamp parle des ready-made. Phillipe Collin et L'Echoppe, Paris, p 22

Hervieu B, Viard J (2001) Au bonheur des campagnes. Éd. de l'Aube, La Tour-d'Aigues, p 155

Hervieu B, Viard J (2005) Au bonheur des campagnes et des provinces. Ed. de l'Aube, La Tour d'Aigues, p 153

Le Dantec JP (1996) Jardins et paysage. Textes critiques de l'antiquité à nos jours. Larousse, Paris, p 634

Le Dantec JP (2006) Mouvance: du jardin au territoire II, soixante-dix mots pour le paysage. Ed. de la Villette, Paris

Lévy J (2002) Sur les conditions d'habitabilité de l'espace. Annales de géographie 111 (626):395-405

Littré PE (1994) Littré. Encyclopedia Britannica Inc., tome V, Chicago

Maderuelo J (2005) El paisaje: génesis de un concepto. Abada Editores, Madrid

Mérot A (2009) Du paysage en peinture dans l'Occident moderne. Gallimard, Paris, p 443

Mohen JP (1999) Les sciences du patrimoine. Odile Jacob, Paris, pp 17-18

Montricher N (1995) L'aménagement du territoire. La Découverte, Paris, p 124

Morin S (2001) Progrès, paysages et identités dans les hautes terres camerounaises. Les montagne tropicales, 16

Nora P (2001) “Introduction”, Tri, Sélection, Conservation, Quel patrimoine pour l'avenir?. Ed. du patrimoine, Paris, pp 15-17

Nys P (1999) Le jardin exploré: une herméneutique du lieu. Les Ed. de l'Imprimeur, Besançon, p 247 
Rey A (1992) Grand Robert de la langue française (2ème édition). Tome VII, Dictionnaire Le Robert, Paris

Rio de Janeiro Summit Conference (1992) The United Nations conference on environment and development report, 3-14 June 1992

Simpson JA, Weiner ESC (eds) (1998) The Oxford English dictionary, vol VIII. Clarendon, Oxford, pp 628-629

Staszak JF (1998) Dans quel monde vivons-nous? Les discours du géographe. L’Harmattan, Paris 